\title{
DNAJB6 wt Allele
}

National Cancer Institute

\section{Source}

National Cancer Institute. DNAIB6 wt Allele. NCI Thesaurus. Code C102931.

Human DNAJB6 wild-type allele is located in the vicinity of $7 q 36.3$ and is approximately 82 $\mathrm{kb}$ in length. This allele, which encodes Dnaj homolog subfamily B member 6 protein, plays a role in the regulation of protein folding and aggregation. Mutation of the gene is associated with limb-girdle muscular dystrophy type 1E. 